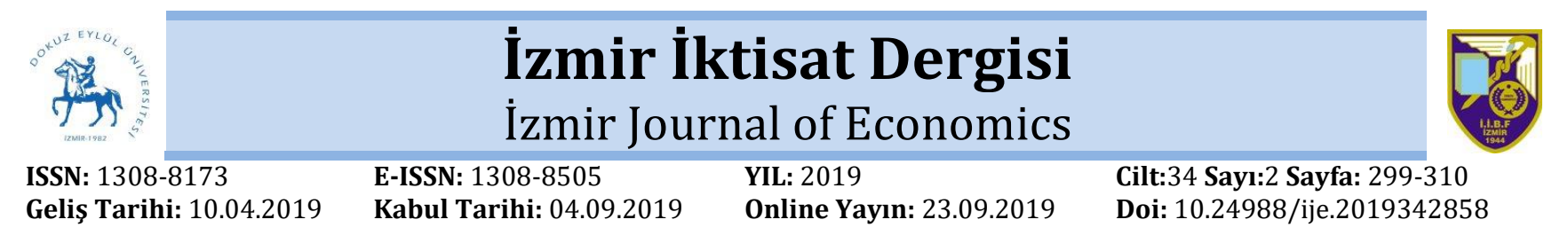

\title{
Türkiye’nin Yeni Hükümet Sisteminde Siyasi Denetim: 2018 Haziran Seçim Sonuçları Özelinde Bir Analiz
}

\author{
Hüseyin GÜL ${ }^{1}$ \\ $\ddot{O}_{z e t}$
}

\begin{abstract}
Türkiye'de sistem değişikliğinin savunanların temel argümanlarından biri, devletin daha hızlı karar alması ve güçlü bir devlet idaresi kurulması gerekçesine dayanmaktadır. Türkiye'de zaman zaman dile getirilen sistem değişikliği 16 Nisan 2017 tarihinde yapılan anayasa değişikliği ile somutlaştı. Böylece Türkiye'de 1876 Kanun-I Esasi ile başlayan parlamenter sistem modeline yönelik birikim, bu anayasa değişikliği ile son bulmuş oldu. Anayasal bir tanımlama olmamakla beraber Cumhurbaşkanlığı Hükümet Sistemi olarak literatüre sokulan yeni bir hükümet sitemi ve bu sisteme dayanan "yeni denetim" olgusu önemli bir konu halini almış oldu. Her hükümet sisteminin başarısı, devlet organları arası karşılıklı "dengedenetleme" araçlarına ve getirilen "kurallara" uymasına bağlıdır. Dolayısıla sistemin başarısı "denetimin" etkinliğine ve denetimi yapan organın kararlarının uygulanmasına dayanmaktadır. Bu çalışmada, Türkiye'nin yeni hükümet sistemi olan Cumhurbaşkanlığı Hükümet sisteminde, "siyasi denetim" olgusu 24 Haziran 2018 seçim sonuçlarına göre bir analize tabi tutulmuştur. Yasama- yürütme ilișkileri yeni sistemin getirmiș olduğu etkileşim araçları bakımından değerlendirilmiş ve sistemin işleyişi üzerinde ne kadar etkin olup/olamayacağı, Meclis aritmetiğine dayanılarak tartışılmıştır.
\end{abstract}

Anahtar Kelimeler: Denetim, Siyasi Denetim, Cumhurbaşkanlığı, Hükümet Sistemi

JEL KOD. KO, K1, M4

\section{Political Audit in Turkey's New Presidantial System: An Eveluation for The June 2013 Election Results Abstract}

One of the basic arguments of the proponents of the system changes in Turkey, the state is based on the grounds quicker decision-making and the establishment of a strong state administration. The system change voiced from time to time in Turkey was held on April 16, 2017 embodied by constitutional amendment. Thus, accumulation for the parliamentary system starting with 1876 Kanun-i Esasi in Turkey, has been ended with this constitutional amendment. Although there is no constitutional definition, the new government system, which was introduced as a Presidential Governmential System, and the litareture "new audit" phenomenon based on this system became an important issue. The success of each government system depends on the mutual "balance-control" tools and the rules-introduced by the state bodies. Therefore, the success of the system is based on the effectiveness of the in audit and the implementation of the decisions of the supervising body. In this study, Turkey's new government system that presidential governmential system, "political audit" has been subjected to an analysis on the facts of the 24 th June 2018 election results. Legislative-executive relations are evaluated in terms of the interaction tools introduced by the new system and the effectiveness of the system on the functioning of the system will be discussed on the basis of the parliamentary arithmetic.

Keywords: Audit, Political Audit, Presidency, Governmential System

JEL KOD. KO, K1, M4

\section{GíRiş}

Devlet idaresi, çeşitli organlar ve bu organların işlevlerinden oluşan bir bütündür. Günümüz modern devletlerinde devlet yönetimi, bu organlar arasında bölüştürülür ve organlar arası ilişki biçimine göre farklılaşan siyasi sistemlere dayanılarak yerine getirilir.
Devletlerin siyasi sistemlerinin farklı olmasının altında yatan sebepler ne olursa olsun her sistemin "yönetimi'nde" belli başlı olgular ortaktır. Yönetme olgusu olarak ifade edilen planlama, örgütlenme, sevk ve idare etme, koordinasyon ve denetleme aşamalarından meydana gelen süreçlerin her devlet

\footnotetext{
${ }^{1}$ Dr. Öğretim Üyesi, Aydın Adnan Menderes Üniversitesi Nazilli İİBF, Nazilli/AYDIN, huseyingul@adu.edu.tr
} 
yönetiminde aynı olduğu kabul edilir (Aydın, 2010:26). Yürütmenin ve yürütme erkini kullananların yerine getirme durumunda olduğu temel fonksiyonlar olarak kabul edilen bu kavramlar içerisinde "denetim" önemli ve farklı bir süreç olarak ayrıca dikkate değerdir.

Çünkü denetleme çeşitli açllardan kategorilere ayrilabilmekte ve yönetim denetlenebilmektedir. Yönetimin denetim süreci, kendi içinde oluşturduğu kurum ve kurallar yoluyla kendini denetleyebileceği gibi kendi dişında başkaca kurumlarca da denetim şeklinde olabilmektedir. Burada kastedilen yürütme organının yani idarenin dış denetimidir ki, bu denetimde idarenin dışında ayrı ve bağımsız organlar bu süreçte rol alırlar. $\mathrm{Bu}$ denetimler de farkl kategorilere ayrılmaktadır. Konu ile ilgili birçok çalışmada yürütme organının dış denetim yoluyla denetlenmesi siyasi denetim, yargı denetimi, ombudsman (kamu denetçisi) denetimi, kamuoyu ve baskı grupları denetimi, medya denetimi ve uluslararası denetimi șeklinde sinıflandırılır (Eryılmaz, 1994:313). Her bir denetimin etki derecesi, denetimi yapan organ ve bu organın verdiği kararın yürütülmesi bakımından farklılı göstermektedir. Dolayısıyla oldukça kapsamlı ve bir o kadar ö önemli bir konularına başında yürütmenin denetimi gelmektedir. Çalışmada diş denetim yollarından bir olan ve yasama organı tarafından yapılan siyasi denetim olgusu ele alınmıştır. Çalışma, 1982 Anayasasında 2017 tarih ve 6771 sayılı anayasa değişik kanunu sonucu oluşan "yeni yasama-yürütme" ilişkilerini, seçilmiş temsilciler eliyle yapılan (Örnek,1994:247) ve TBMM'nin "siyasi denetim yetkisi" etkinliği çerçevesinde 24 Haziran 2018 seçim sonuçlarına göre irdelemiştir.

\section{DENETIMM KAVRAMI VE KAPSAMI}

Modern ulus devletler, kamusal mal ve hizmetleri, toplumun ihtiyaçlarını göz önüne alarak idari bir teşkilatla (devlet idaresi) sunarlar. Devlet, idari teşkilat yoluyla kamu hizmetlerini yerine getirirken; idari işlem ve eylemlerde bulunur. işte bu idari işlem ve eylemler devletin çeşitli organları tarafindan bazı durumlarda denetime tabi kılınır. Hukuk devleti olarak ifade edilen bu süreç aslında idarenin işlemlerinin denetimidir. (Any.m.125). Hukuk devleti, en dar anlamıyla hukuka baglı devlet demektir. Ayrıca hukuk devleti, faaliyetlerinde hukuk kurallarına bağlı olan, vatandaşlarına hukuki güvenlik sağlayan devlet (Özbudun, 2011:123) olarak ifade edilir. Gelişmiş demokrasilerde, hukuk devleti anlayışına çeşitli aşamalardan geçilerek ulaşılmıştır (Gözler, 2018a:23). Bugün gelinen noktada demokratik rejimlerin temel niteliklerinden birisi olarak hukuk devleti, genel kabul görmektedir. $\mathrm{Bu}$ nedenledir ki, idari faaliyetlerin her aşamasında denetim, denetimi yapacak organ ve denetimin sonucu verilen karar, hukuk devleti varlıgı açısından önemlidir. 1982 Anayasası, idarenin işlem ve eylemlerine karşı yargısal yolu kabul etmiş ve aynı zamanda idarenin farklı yollarla denetleneceğini hüküm altına almıştır.

Denetim, yönetimin belirlenen amaçları doğrultusunda planlanan ve yapılması istenen faaliyetlerin yapılıp yapılmadığının, yapılmış ise ne kadar doğru ve etkin olup olmadığının öğrenildiği son süreçtir. Denetim teriminin sözlük anlamı, "bir işin doğru ve yönetimce uygun olarak yapılıp yapılmadığını incelemek, gözaltında bulundurmak" manasına gelmektedir. Denetim, salt "seyircilik" olmadığına göre, bu anlam yetersiz kalır. Denetimin "anlama" ile sinırlı bu pasif boyutunun yanı sıra, bir de "belli bir işlem, eylem veya durumun belli bir kurala uygunluğunu sağlamak için ona karışma" biçiminde tanımlanabilecek, etkin bir yönünün bulunduğu da açıktır (Eroğlu, 1978:36). Aydın; denetim sürecini, “örgütçe benimsenen amaçların ya da üstlenilen görevlerin eksiksiz, verimli ve zamanında gerçekleşip gerçekleşmediğinin hiyerarşi içinde ve yaptırımlı bir biçimde izlenmesi ya da işleyiş̧teki aksaklıkları saptayarak bunların düzeltilmesini, görevlilerin daha iyi çalışmasını sağlamaya yönelik bir eylem" olarak tanımlar (Aydın, 2010:68). Denetim süreci, devletin organları olan yasama, yürütme ve yargıda farklı şekillerde 
olabilmektedir. Kısaca yasama denetimi, temsili demokrasilerde, ulusal iradeye üstünlük sağlamanın doğal gerekleri arasında yer alır. Yürütme alanındaki denetim, hizmete bağlı kimi sonuçların alınması amacıyla kullanılır. Yargı denetimi ise hukuk devleti olmanın ilk koşuludur.

Demokratik hukuk devletlerinde "denetim", kaynağını bașta anayasa olmak üzere yasa ve diğer düzenleyici işlemlerden alır (Gözübüyük\&Tan, 2003:30). Bu anlayış, Türkiye'de geçmiş anayasalarda olduğu gibi 1982 Anayasası'nda da anayasal hükümle belirlenmiștir. 1982 Anayasası 2. maddesi devletin niteliklerinden birinin "hukuk devleti" olduğuna ilişkin hükmü barındırır. Hukuk devletinin en temel gereklerinden biri de idarenin yargısal denetime tabi tutulmasıdır. Keza 125. madde, "idarenin her türlü eylem ve işlemlerine karşı yargı yolu açıktır" hükmünü düzenlemiș ve yargısal denetim yolu anayasal güvenceye alınmıştır. Yine anayasanın 123. maddesiyle, "idare, kuruluş ve görevleri ile bir bütündür ve kanunla düzlenir" hükmü getirilmiştir. Hukuk devleti ilkesinin en önemli gereği, idarenin yapmış olduğu işlem ve eylemlerin hukuka uygunluk yönünden çeşitli denetimlere tabi olmasıdır. Anayasa, yargı denetimi ile beraber idari, siyasi ve kamu denetçiliği kurumu (ombudsman) şeklinde idari işlem ve eylemlerin hukuka uygunluğun denetleneceğine ilişkin farklı maddelerde hükümlere yer vermiştir. Günümüzde yargı dışı denetim yolları da en az yargı denetimi kadar etkin ve önemlidir. Yargı denetimi ile idari işlem ve eylemlerinin sadece hukuka uygunluğu denetlenirken; yargı dışı denetim yolları ile idari işlem ve eylemlerin sadece hukuka uygunluğu değil, aynı zamanda yerindeliği de denetlenmiş olur (Gözler, 2018a:385). Yargı denetimi belli usul kurallarına bağlanmıştır, oysa yargı dışı denetim yolları, çoğu kez bir başvuruya gerek olmaksızın kendiliğinden harekete geçebilir ve ayrıca daha basit usullere tabidir. Bu yönüyle daha az maliyetli olduğu gibi kararların hızlı alınmasına da yol açar.
Yargı dışı denetim yolarından biri TBMM'nin siyasi denetim yoluyla yürütme organını denetlemesidir. Siyasi denetim, yürütmenin işlem ve eylemlerinin yasama organı tarafından denetlenmesidir ki bu usulle yürütme üzerinde yasamanın etkinliği sağlanır. Ayrıca yürütmenin, halkın doğrudan seçtiği temsilciler vasıtasıyla denetlenmesi, yürütmenin işlem ve eylemlerinin kamuoyunun gündemine gelmesine yardımcı olur. Cumhurbaşkanlığı Hükümet Sisteminde (CHS) siyasi denetim yetkisine sahip TBMM'nin hangi araçlar ile denetim yapacağı hususu, sistemin başarısı ve demokratik niteliği oldukça önemli bir konudur. Dolayısıyla öncelikle yeni hükümet sisteminin kuvvetler ayrılığ teorisi çerçevesinde ne gibi özelliklere haiz olduğuna bakmak gerekecektir. Sonrasinda ise yeni sistemin TBMM'e yani yasama organına tanımış olduğu siyasi denetim yetkisinin neler olduğu ortaya konulacak ve bu yetki araçları 24 Haziran 2018 seçim sonuçlarına göre oluşan TBMM sandalye dağılımına göre bir değerlendirmeye tabi tutulacaktır.

\section{CUMHURBAŞKANLIĞI HÜKÜMET SISTEMININ GENEL ÖZELLIKKLERI}

Türkiye, 16 Nisan 2017 tarihinde yapılan Anayasa referandumu sonucunda yeni ve farklı bir siyasi sisteme geçişi oyladı. Cumhurbaşkanlığı Hükümet Sistemi olarak adlandırılan ve hükümet sistemleri tipolojisinde Başkanlık Hükümet sistemine tekabül eden bu yeni sisteminde, yürütme yetkisi ve görevi başkanlık sistemlerinde olduğu gibi tek kişi de, Cumhurbaşkanında toplanmıştır. 24 Haziran 2018 tarihinde yapılan Cumhurbaşkanlığı ve T.B.M.M. seçimleri ile birlikte bu sisteme, ilk kez doğrudan halk tarafindan seçilen Cumhurbaşkanının, 9 Temmuz 2018 tarihinde TBMM önünde and içmesi ile uygulamaya geçti. Cumhurbaşkanlığı Hükümet Sisteminde, yasama ve yürütme organları arasında ilişki "katı kuvvetler ayrıllğına" (Gözler, 2017:232) dayanmaktadır. Bu sistemin en belirgin yönü yürütme organının tek kişiden oluşması ve doğrudan halk tarafından seçilen yürütme 
(cumhurbaşkanı) ve yasama (TBMM) meşruiyetini halktan alması ve sabit görev süresi (beş yll) için herhangi başka bir güvene gerek duyulmaksızın görevini sürdürmesidir.

CHS'de devlet organları gerek kaynak gerekse varlıklarını sürdürmeleri bakımından birbirlerine karşı bağımsızdırlar. Bu organların görev ve yetkileri anayasal sistem içerisinde belirlenmiştir. Bu katı ayrılık sebebiyle CHS tipik "başkanlık sistemi" özelliğine sahiptir. Bu özelliğine karşın CHS'nin kendine has bir ayırıcı yönü bulunmaktadır ki o da "seçimlerin yenilenmesi yetkisinin" bu sistem de hem Cumhurbaşkanına hem de TBMM'ye tanınmış olmasıdır. Uygulamada tek tip başkanlık sistemi tanımı mümkün olmadığına göre (Uluşahin, 1999: 225) bu ayırıcı yön sistemin Türk tipi başkanlık olarak nitelenmesine neden olmuştur. Böylesi bir yetkinin her iki organa verilmesi, organlar arası çıkabilecek kilitlenme/kriz ihtimaline karşı sistemin ișler kılınmasını sağlama amacıdır. Linz bașkanlık sisteminin kilitlenmesi ihtimalinin sistemin katılığına vurgu yaparak esnek olmadığını ifade etmektedir (Sartori, 1997:125). CHS'ne konulan bu yetki yoluyla sistemin kriz riski asgari düzeye indirilmeye çalışılmıştır.

CHS'de Cumhurbaşkanı, doğrudan halk tarafından seçildiği için yasama organına karşı siyasi bir sorumluluğu yoktur. Bununla birlikte TBMM'nin seçim kararı alması durumunda görev süresini sonlandırması söz konusu olabilir (Any. m.116). Yine ayrıca başkanlık sistemlerinde var olan suçlama usulü ile yasama organı tarafından cezai sorumluluğun doğmasına yol açılması da muhtemeldir. (Any. m.105). Cezai sorumluluk, başkanlık sistemlerinden farkl olarak görevinin sona ermesinden sonra dahi işletilebilecek bir mekanizma olmasına karşın; bu yetkinin işletilebilmesi Anayasa'da oldukça zor koşullara bağlanmıştır.

CHS'de yürütme tek kişiden oluşmaktadır. Ancak Cumhurbaşkanı, yürütme yetkisini atayacağı cumhurbaşkanı yardımcıları ve bakanlar eliyle kullanacaktır. Bunların sorumluluğu Cumhurbaşkanına karşıdır. Bir nevi cumhurbașkanının sekreterleri olarak onun adına görevlerini ifa edecek olan yardımcı ve bakanların kollektif sorumlulukları bulunmadığı gibi, TBMM'ye karşı da bir sorumlulukları olmaz. Bunlar aynı zamanda her iki organda aynı anada görev alamazlar. Katı kuvvetler ayrılığı sisteminin belirleyici özelliklerinden biri olan bu husus, CHS içinde geçerlidir. Kendine has özellikler nedeniyle hem parlamenter hem de başkanlık sisteminden ayrılan Cumhurbaşkanlığı Hükümet Sistemi bu yönüyle Türk tipi başkanlık olarak nitelenmektedir. Gözler, bu yen hükümet sistemini "neverland hükümet sistemi" olarak ifade etmektedir (Gözler, 2018:286).

Sistemin yürütme ve yasama organın kuruluş ve işleyişine ilişkin usuller 2017 tarih ve 6771 sayılı anayasa değişiklik kanunu ile düzenlenmiștir. Dolayısıyla bu yeni sistemde devlet organlarının birbirlerini "dengedenetleme" araçları ile etkilemeleri ve bu yolla iş birliği yapma usulleri "sistemin ruhuna" uygun düzenlemiştir. CHS'de yasama organının, yürütme organı (Cumhurbaşkanı, Cumhurbaşkanı yardımcısı ve Bakanlar) üzerinde çeşitli araçlarla denetim yapma yolu 1982 Anayasasının 7, 87, 98, 105, 106, 116, 161. maddeleri uyarınca TBMM'ye tanınmıştır. TBMM'ye tanınan bu yetkiler kanun yapma, bilgi edinme ve denetim yollarını kullanma, seçimlerin yenilenmesi kararı alma gibi anayasal yetkilerdir. Anayasa, Meclisin üstünlüğü prensibine dayalı olarak yürütmenin çeşitli araçlarla denetlemesini mümkün kılınmıştır. Bunların ayrıntıları anayasada doğrudan ve dolaylı olarak yer almıştır. Siyasi denetim olarak ifade edilen bu denetim yolları aşağıda ele alınmıştır.

\section{CUMHURBAŞKANLIĞI HÜKÜMET SISTEMINDE TBMM'nin SIYYASI DENETIMİ}

Türkiye'de 16 Nisan 2017 Anayasa referandumu ile başlayan hükümet sistemi değişiklik serüveni 24 Haziran 2018 tarihinde yapılan seçimlerle birlikte "yasama-yürütme" alanında köklü bir değişiklikle nihayete 
ermiștir. 24 Haziran 2018 tarihinde yapılan ilk seçimlere altı cumhurbaşkanı adayı katılmıştır.

Yürütme organı seçim sonuçlarına göre; Recep Tayyip Erdoğan, 50.068.627 geçerli oyun26,330,823 (\%52.6-, ile Cumhurbaşkanlığını kazanmıştır (ysk.gov.tr). Böylelikle Cumhurbaşkanlığı seçimi ilk turda neticelenmiş ve Türkiye'de 1876 Anayasası ile başlayan parlamenter sistem geleneği bu sonuçlarla son bulmuştur. Recep Tayyip Erdoğan, AK Parti ve MHP'nin “Cumhur İttifakı" adayı olarak seçimlerde yürütme görevini ilk turda kazanarak Türkiye'nin yeni sisteminin ilk seçilmiş Cumhurbaşkanı unvanını elde etmiştir. Artık Türkiye'de, doğrudan halk tarafından belirlenen bir yürütme organı ve halktan aldığg yetki ile yürütme görevini tek başına yerine getiren Cumhurbaşkanı söz konusudur.

24 Haziran 2018 seçimleri Türk yönetim tarihi içinde ilk kez farklı ve denenmemiş bir yönetim sistemi olarak uygulamaya geçmiş oldu. Aynı zamanda ilk kez devlet iktidarları olan yasama ve yürütme organının eş zamanlı belirlendiği bu seçim ile birlikte her iki organ ayrı ayrı halk tarafından belirlendi. $\mathrm{Bu}$ seçimler aynı zamanda ülkede çoğunluğa dayalı bir yürütme iktidarını (cumhurbaşkanı) zorunlu kıldığı için seçim öncesinde siyasi partiler, Cumhurbaşkanı adayları üzerinde ittifaklar yapmak suretiyle seçimlere katıldılar. 24 Haziran 2018 Yasama (TBMM) seçim sonuçları aşağıda ifade edilen netice ile sonuçlanmıştır.

- $\quad$ Cumhur ittifakı (AK Parti-MHP): \%53,7, 26,900,096 oy 344 Milletvekili (295 AK Parti- 49 MHP)

- $\quad$ Millet İttifakı (CHP-iYİ Parti-SP): \%33,9, 17,013,340 oy, 189 Milletvekili (CHP-146, IYI Parti 43)

\section{- HDP: \%11,7, 5,866,309 oy, 67} Milletvekili çıkarmıştır (ysk.gov.tr/).

TBMM seçim sonuçlarına göre de Cumhurbaşkanı adayı ortak olan Cumhur ittifakı, TBMM'de de çoğunluğa sahip olmuştur. En çok sandalyeye sahip Cumhur İttifakl, Cumhurbaşkanı (yürütme) organı ile uyumlu çalışma konusunda Mecliste çoğunluğa sahiptir. Haliyle yasama-yürütme arasında seçim sonuçlarına göre bir uyum ve ahenk söz konusu olmuştur. Ancak bu uyum ittifakla sağlanabilmiştir. Haliyle Türkiye'de yeni sistemin ahenk içinde işleyebilmesi için hem yasama hem de yürütme organı seçimlerinde siyasi ittifaklar kaçınılmazdır. Yukarıda verilen sonuçlar bunu doğrular niteliktedir. Bu yönüyle her iki organda birlikte hareket eden/edebilen siyasi ittifaklar arasında seçim sonrası çıkabilecek uyuşmazlıklar söz konusu olur ise yasama ve yürütme ilişkileri, örneğin cumhurbaşkanının politikalarını uygulaması, kanuna ihtiyaç duyması, bütçesinin kabulü gibi konularda organlar arası kriz çıkma ihtimali söz konusu olabilecektir. Bu yüzdendir ki yeni sistemin siyasi denetim olgusu önemli bir konu olarak irdelenmelidir.

Esasinda sistem ister parlamenter olsun ister başkanlık sistemi olsun yürütmenin denetlenmesi gerekmektedir. $\mathrm{Bu}$ denetim mekanizmaları arasında en bilineni şüphesiz yargı denetimidir. Hukuk devletinde, idarenin yargı denetimi dışında, idari, siyasi ve kamuoyu yoluyla denetlenmesi de mümkündür. Anayasa, CHS'de yasama organının denetim yollarını hüküm altına almış ve yürütmeyi hangi hususlarda, hangi denetim mekanizmalarını kullanarak denetleyeceğini ifade etmiștir. Bu kısımda seçim sonuçlarına göre TBMM'nin doğrudan ve dolayalı olarak yürütme (cumhurbaşkanı) kullanabileceği/denetleyebileceği anayasal yetkiler, Mecliste grubu bulunan siyasi partilerin sandalye dağılımına göre bir analize tabi tutulmuştur.

\subsection{Türkiye Büyük Millet Meclisinin Doğrudan Yaptığı Denetim}

Cumhurbaşkanlığı Hükümet Sisteminde yasama yetkisi TBMM'dedir. Bu yönü ile sistem, meclisin üstünlüğü ve yasamanın asilliği prensibine dayanmaktadır. Anayasanın 6 . maddesine göre "Türk Milleti, egemenliğini anayasanın koyduğu esaslara göre yetkili organlar eliyle kullanır". Kaynağını anayasadan almayan bir devlet yetkisi kullanılamaz. Anayasa, yetkili organları ve hangi yetkinin 
hangi organa ait olduğunu belirlemiştir. Anayasasın 7. maddesine göre, yasama yetkisi, "Türk milleti adına TBMM aittir". Bu yetkiyi kullanan Meclisin, yürütmeyi ve onun idari işlem ve eylemlerini denetlenmesinde etkin bir konumda olması, demokratik hukuk devletinin gereğidir. TBMM bu denetimi anayasadan aldığı yetki ile çeşitli araçlar eliyle yapmaktadır.

\subsubsection{Kanun Yapma Yetkisi}

1982 Anayasasının 87. maddesi uyarınca TBMM'ne tanınmış asli yetki "kanun yapma" yetkisidir. Kanun, yasama organınca çıkarılan genel, soyut ve kişilik dışı sürekli uygulanan maddi ve şekli hukuk kurallarını ifade eder (Sancaktar, 2018:62). Yürütmenin idari faaliyetlerini yerine getirebilmesi için ihtiyaç duyduğu/duyacağı kanunların çıkarılması için yasama organına bağımlılığı söz konusudur.

2017 tarih ve 6771 sayılı anayasa değişikliği kanunun getirmiş olduğu önemli yeniliklerden biri, Kanun teklif etme yetkisinin sadece "milletvekillerine" ait olduğuna ilişkin düzenlemesidir. Kanun tekliflerinin Türkiye Büyük Millet Meclisinde görüşülme usul ve esasları TBMM İçtüzüğe göredir. Mevcut durumda ve anayasada belirlenmiş olan 96 . madde uyarınca "Türkiye Büyük Millet Meclisi, yapacağı seçimler dahil bütün işlerinde üye tamsayısının en az üçte biri ile toplanır. Türkiye Büyük Millet Meclisi, Anayasada başkaca bir hüküm yoksa toplantıya katılanların salt çoğunluğu ile karar verir; ancak karar yeter sayısı hiçbir şekilde üye tamsayısının dörtte birinin bir fazlasından az olamaz" şeklindedir. Dolayısıyla bir kanun teklifinin, TBMM'de kabulü için yeter sayı 151 'den az olamaz. $\mathrm{Bu}$ sayıyı Meclis dağılımına göre ele aldığımızda; Cumhur İttifakı olarak nitelenen AK Parti ve MHP'nin, TBMM de çoğunluğa sahip olduğu (340 üye) ve her hâlükârda ittifakla "kanun yapma" yetkisini kullanabileceğini söylemek gerekir.

Yeni sistemde kabul edilen bazı kanun ve nisaplara baktığımızda, Meclisin, kanun yapma yetkisini kullanması bakımından herhangi bir sorunla karşılaşılmayacağını söylemek mümkündür. Örneğin 7145 sayılı Kanun Genel
Kurulda bulunan 338 üyenin 282 kabul 56 ret; 7146 sayılı Kanun 247 üyenin 218 kabul, 29 ret; 7148 sayılı Kanun 259 üyenin 230 kabul, 29 ret şeklinde sonuçlandığı görülmektedir (www.tbmm.gov.tr /kanunlar). Bu sonuçlardan hareketle TBMM'nin kanun çıkarma yetkisini kullanırken TBMM üye tamsayısının 1/3'den fazla üye ile toplandığı ve toplantıya katılanların salt çoğunluğundan fazla bir çoğunlukla kanun çıkardığı görülmektedir. Dolayısıyla bu yetkinin kullanılmasında yasama ve yürütme organları arasında herhangi bir uyuşmazlık söz konusu değildir.

Anayasal sistem TBMM'ye Cumhurbaşkanını, "kanunla" sinırlama yetkisini vermesi yansıra, Cumhurbaşkanının gücünü "kanun yoluyla" yasama organı tarafından dengelenmesine ilişkin hükümleri de düzenlemiştir. Dolayısıyla sistem Cumhurbaşkanını, Meclis ile uyumlu çalışamadığı takdirde hiçbir önemli yetkisini kullanamaz hale getirebilir. Çünkü Meclis, kanun çıkarma yanında, Uluslararası antlaşmaların kanun yoluyla onayı, Cumhurbașkanı kararnamelerinin TBMM tarafından çlkarılacak "kanun" yoluyla iptali yanında, cumhurbaşkanı bütçesinin Meclis tarafından bir kanunla kabul edilmesi/edilmemesi gibi durumlarda Cumhurbaşkanını, Meclis'e bağlı kılmıştır.

CHS'nin asli özelliği yasama ve yürütmenin yani Cumhurbaşkanının, TBMM üyesi olmamasına dayanmasıdır. Ancak bu yni sistemde Cumhurbaşkanı aynı zamanda siyasi parti lideri veya bir partili olmak zorundadır. Kendisi yasama çalıșmalarına katılmasa bile partisinin milletvekilleri yoluyla yasama organında dolaylı kanun teklifi (Çam, 2000:109) yaptırabileceği gibi olağan parti toplantılarında veya medya yolu ile milletvekillerine mesaj göndermek suretiyle harekete geçirebilir. Türk siyasi tarihi ve siyasi partiler kanunu dikkate alındığında bunun oldukça kolay olabileceğini söylemek zor olmaz. Böylece uygulamada TBMM'de sandalye dağılımının Cumhurbaşkanının partisi veya ittifakı lehine olması durumunda yasama etkinliklerinin büyük bir kısmı Cumhurbaşkanının dolaylı 
etkisi altında gerçekleşebilir. Her demokratik sistemde organlar arası uyum ve ahenk sistemin ruhuna uygun araçlarla donatılmıştır. Hem yönetim hem de siyasi parti geleneği bir arada düşünüldüğünde $\mathrm{CHS}$ 'de, sistemin uyum ve ahenk içerisinde sürdürülmesi, devlette birlik ve bütünlüğü sağlamasının mümkün olacağını söyleyebiliriz.

\subsubsection{Seçimlerin Yenilenmesine İlişkin Yetki}

2017 tarih ve 6771 sayılı anayasa değișiklik kanununa göre "Cumhurbaşkanı ve TBMM seçimleri beş yıl da bir yapıllır" şeklindedir. bu hükme karşın anayasa seçimlerin zamanının dışında da yapılabileceğini düzenlemiştir. Buna göre seçim yenileme kararı Cumhurbaşkanı tarafından tek başına alınabileceği gibi, TBMM tarafından da alınabilecektir. Başkanlık sisteminde katı bir ayrllı söz konusu olduğundan, Başkan ve Meclis birbirlerinin görevlerine son veremezler ve seçimlere kadar olası bir uyuşmazlığın önüne geçilemez. Türkiye'nin tarihsel koşulları, siyasal kültürü ve devlet yapısı göz önüne alınarak CHS'de ortaya çıkabilecek herhangi bir kriz ihtimaline karşı önemli bir yetki olarak "seçimlerin yenilenmesi- Any. m.116" düzenlenmiştir. Buna göre TBMM bu yetkiyi beş yıllık süre dolmadan üye tam sayısının bește üçünün kararı ile kullanabilecektir. Böylece bu yetki sayesinde TBMM hem kendi hem de cumhurbaşkanının varlığına son vererek olası sorunların önüne geçebilecektir. $\mathrm{Bu}$ noktadan hareketle TBMM'nin "seçim yenileme" kararı alabilmesi için üye tam sayısı olan 600 milletvekilinden, 360 milletvekilinin onayını alması koşulu gerekmektedir. Mevcut dağllıma göre bu sayının ittifaklar yoluyla dahi işletilmesinin imkânsız olduğunu söylemek mümkündür. Seçimleri yenilenmesi kararının parlamenter sistemin araçlarından biri olduğunu ve kolaylıkla alına bildiğini ifade etmek gerekmektedir. Kaldı ki, Türkiye'de gerek 1990'larda koalisyon hükümetlerinde gerekse AK Partinin tek başına iktidar olduğu 2007 ve 2011 yllarında yasama döneminin sonu beklenmeden seçimlerin erkene alındığı bilinmektedir. Ancak yeni dönemde parlamenter sistemin uygulandığı dönemler deki gibi bu kuralın, TBMM tarafından sıklıkla ve kolaylıkla işletilebileceğini söylemek oldukça güçtür.

Cumhur İttifakı olarak seçimlere giren AK Parti ve MHP'nin toplam üye sayısı (340 üye) dahi seçimlerin TBMM tarafından yenilenmesi kararını tek başına çıkarmaya yetmemektedir. Zira bu kararın verilebilmesi için TBMM'de 360 ve üzeri milletvekilinin ortak irade ortaya koymaları gerekmektedir. Hali hazırda bu sayı Cumhur İttifakı bozulsa bile -AK Parti'nin toplam üye sayısının 290 olduğu göz önüne alındığında- diğer partiler yoluyla işletilebilmesi güç gözükmektedir.

\subsubsection{Bütçe Denetimine İlişskin Yetki}

Meclislerin en temel yetkilerinden biri olan "Bütçe yetkisi" (Ertekin\&Gül, 2018:282) bir denetim mekanizması olarak CHS'de anayasal yetki (Any. md. 161) olarak düzenlenmiştir. Parlamentoların "temsilsiz vergi olmaz" ilkesi etrafında ilk kez İngiltere'de ortaya çıkan bu mali yetki ile yürütmenin harcamalarının kanuni denetimi sağlanmıștır (Gözler, 2018;268). CHS'de Cumhurbaşkanı, program ve projelerini gerçekleştirmek için bütçeye ihtiyaç duyacaktır. Cumhurbaşkanının, yürütme görevini yerine getirebilmesi için bütçeye olan ihtiyacı düşünüldüğünde, bütçeyi onama/onamama yetkisinin TBMM verilmiş oldukça önemli bir yetki olduğunu söylemek gerekmektedir (Gül, 2018;170).

Cumhurbaşkanı, Devlet bütçesini "kanuna" dayandırmak zorunda olacağından ya Türkiye Büyük Millet Meclisinde çoğunluğa sahip olacak ya da böyle bir çoğunluk yoksa diğer siyasi partilerle uzlaşı arayacaktır. Bu durumda Meclis, Cumhurbaşkanının bütçe ve kesin hesap kanun teklifini ya kabul ya da reddetme yolu ile denetleyebilecektir. Anayasanın 161. maddesi Bütçe ve Kesin Hesap kanun teklif yetkisini Cumhurbaşkanına tanımıştır. CHS'de, Bütçe yapma yetkisi cumhurbaşkanına tanınmış istisnai bir durumdur. Ancak bütçenin yürürlüğe girmesi için TBMM'nin onayl gerekmektedir. Meclis'in, bütçeyi kabul 
etmeme yetkisi ve kabul ettiği bütçenin harcamalarını da denetleme sorumluluğu vardır. Anayasa TBMM'nin, Cumhurbaşkanı'nın sunduğu yeni bütçeyi kabul etmemesi durumunda geçici bütçe kanunu çıkarılacağını, geçici bütçe kanunu çıkmaması durumunda ise bir önceki yılın bütçesinin yeniden değerleme oranına göre artırılarak uygulanacağını düzenlemiştir. (Any, md 161/4).

CHS'de bütçe yetkisi, esasında demokratik sistemlerde parlamentolara tanınmış yetki olmasına karşın; CHS, bu yetkinin kullanılması noktasında her iki organın uzlașısını aramış, devlet faaliyetlerinin yürütülmesi için gerekli olan gelir ve giderlerin belirlendiği bütçede kriz çıkmasının önüne geçilmek istenmiştir (Ertekin\&Gül, 2018;290). Bu sistemde Cumhurbaşkanı'nın bütçesinin geçmemesi durumunda kamu hizmetlerinin aksaması, vergi toplanılamaması veya harcama yapılamaması söz konusu olmayacaktır. Haliyle yasamanın bu yetkisini cumhurbaşkanına karsı kullanması etkin bir sonuç doğurmayacaktır. Çünkü bu denetim yetkisi etkin bir araç değildir. (Gözler, 2018;269). Kaldı ki bütçe kanunu da diğer kanunların tabi olduğu hukuki rejime tabidirler ve toplantl ve karar yetersayısı bakımından aynı rejim söz konusudur. Mecliste, siyasi partilerin dağılımı dikkate alındığında Cumhur İttifakının diğer ortağı, Cumhurbaşkanının bütçesine ret verse dahi ya geçici bütçe kanunu ya da bir önceki yıl bütçesi değerlenme oranında yürürlüğe girecek, vergi toplanabilecek, harcamalar yapılabilecektir.

\subsubsection{Cumhurbaşkanının Düzenleyici İşlemlerine İlişkin Yetki}

Meclisin yasama yetkisi üzerinden denetim yapabileceği bir diğer konu da Cumhurbaşkanının düzenleyici işlemlerine karşı yetkisidir. 9 Temmuz 2018 tarihinde yürürlüğe giren $\mathrm{CHS}^{\prime}$ de düzenleyici işlem olarak Cumhurbașkanına "Cumhurbaşkanlığı Kararnamesi" ve "Yönetmelik" çıkarma olmak üzere iki düzenleyici işlem yetkisinin tanındığ görülmektedir. Yürütmenin faaliyetlerinde ve uygulamalarında etkin olabilmesi, düzenleyici işlem yapma yetkisine sahip olması ile mümkündür. Başkanlık hükümet sistemlerinde devlet başkanına, yürütme alanını düzenleme yetkisi tanınmıştır. Yürütmenin başı olan cumhurbaşkanına uygulamak istediği politikaları hayata geçirebilmesi için "yürütme emirleri" olarak adlandırılan "düzenleyici işlem yapma" yetkisinin verilmesi başkanlık sistemlerinde (Gülener\&Miş, 2017:62) olduğu gibi parlamenter sistemlerde de Bakanlar Kuruluna verilen Kanun Hükmünde Kararname yetkisi gibidir. CHS'de Cumhurbaşkanının kararname ile yürütme alanında "kendine özgü" bir düzenleyici işlem yapma yetkisi tanınmıştır.

Cumhurbaşkanlığı kararnameleri anayasada iki farklı şekilde yer almıştır. Birincisi, Cumhurbaşkanının yürütme alanında kararname çlkartma yetkisinin bizzat anayasada düzenlenmiş olmasıdır. (Any. m.104). İkincisi ise, Cumhurbaşkanı kararnamelerinin yasa gücünde olmasıdır. Yasa gücünde kararnameler, hiyerarşik olarak Anayasa ve kanunların altında olduğu gibi kanunla düzenlenen bir alanda Cumhurbaşkanını kararname çıkaramayacaktır. Anayasa, Cumhurbaşkanının kararname çıkarma yetkisini çeşitli sinırlamalara tabii kılınması yanı sıra Meclis tarafından denetimini de ayrıca düzenlemiștir. Olağan dönem kararnameler, Anayasanın 104/17. firkasinda belirlenen anayasal sinırlamalara tabi kılması yanı sıra Meclis tarafından çıkarılacak bir kanunla hükümsüz kılınabilecektir. Bir konuda kanun var ise kararname çıkarılamayacak, kanun çıkmışsa daha evvel çıkarılan kararname kadük hale gelebilecektir. $\mathrm{Bu}$ yönüyle yasamanın ve kanunların üstünlüğü prensibi geçerli olacaktır. Olağanüstü dönemde çıkarılacak kararnameler ise anayasa da belirlenen (Any. m.119 ve Any md.14-15) sınırlar yanı sıra kararnamenin üç ay içerisinde Meclis tarafından kabul, red veya değiştirilmelerine ilişkin açık sınırlandırmalar söz konusudur.

$\mathrm{Bu}$ yetkinin kullanılmasında usul tıpkı kanun çlkarma da ki usul ve esaslara göredir. Seçim sonuçlarına göre oluşan dağılıma bakıldığında 
TBMM'nin olağan dönemlerde cumhurbaşkanı tarafından çıkarılan kararnameleri bir kanunla "kadük hale" getirme çoğunluğuna sahip olmadığı görülmektedir. Olağan üstü dönemin koşularına göre ise bu yetkinin kullanılması ayrıca düzenlenmiş, bu dönemde çıkarılacak kararnameler için yeni olarak Meclis denetimi koşulu getirilmiştir. Bu dönem kararnameleri için böylesi bir denetimin Meclis tarafından yapılması ayrıca önemlidir.

Cumhurbaşkanına tanınmış diğer bir düzenleyici işlem olan yönetmelikler ise anayasasının 124'üncü maddesine dayanılarak çıkarılan hukuk kurallarıdır. Bunların hukuku rejimi ve denetimleri ise idare hukuku kuralları ve idari yargı yolu ile yapılmaktadır (Gözler, 2018a:232).

\subsubsection{Cumhurbaşkanının Cezai Sorumluluğuna İlişskin Yetki}

Başkanlık sistemlerinde, başkanın cezai sorumluluğu (impeachment) ile ilgili olarak öngörülmüss bir yol olarak görülen denetim aracı (Eroğlu, 1996:88; Yazıcı, 2013:39; Şahin, 2001:62) CHS'de de yer almıştır (Any. md. 106) Bu yetki sayesinde, Cumhurbaşkanının, yasama organı tarafından denetlenmesi ve cezai sorumluluğu ile ilgili olarak TBMM tarafından suçlanması söz konusu olabilir. Bu yetki ile TBMM, Cumhurbaşkanlığı görevini sona erdirebilecek mekanizmayı harekete geçirebilir ve sonucunda Cumhurbaşkanının, Meclis tarafından soruşturulması ve Yüce Divan sıfatıyla Anayasa Mahkemesinin vereceği bir yargı kararı ile görevi sonlandırılabilir.

Meclis, Cumhurbaşkanının cezai sorumluluğuna yol açabilecek böyle bir yetkiyi kullanabilmesi anayasanın 105. maddesinde belirlenmiş olan usule göredir (İçtüzük md.114). Buna göre Cumhurbaşkanı hakkında meclis sorușturması açılabilmesi için üye tam sayısının salt çoğunluğunun (301 üye) bir soruşturma önergesi vermesi ve önergenin üye tam sayısının 3/5'inin (360 üye) Meclis Genel Kurulunda kabul etmesi gerekmektedir. Sadece bu hükümlere göre bir tespit yapılacak olunursa 24 Haziran sonrası oluşan Meclis aritmetiğine göre Cumhurbaşkanı hakkında
Meclis tarafından suçlanma yetkisinin kullanılabilmesinin mümkün olmadığı söylenebilir.

\subsection{Anayasa ve Türkiye Büyük Millet Meclisi İç Tüzüğünde Öngörülen Denetim}

Bunlardan ilki anayasanın 98. maddesinde düzenlenmiş olan "Türkiye Büyük Millet Meclisi, meclis araștırması ve genel görüşme, meclis sorușturması ve yazılı soru yolları ile yürütme organı üzerinde bilgi edinme ve denetleme yetkisini kullanır". Meclis araştırması, genel görüşme ve yazılı soru önergelerinin verilme şekli, içeriği ve kapsamı ile araştırma usulleri Meclis İçtüzüğü ile düzenlenir. Buna karşın Meclis soruşturması doğrudan anayasa da düzenlenmiştir. $\mathrm{Bu}$ hükme ve seçim sonuçlarına göre bu yetkilerin kullanılmasında meclisin etkinliğine bakılacak olunursa;

\subsubsection{Yazılı Soru}

Yazılı olarak en geç on beş gün içerisinde cevaplanmak üzere milletvekillerinin, Cumhurbaşkanı yardımcıları ve bakanlara yazılı olarak soru sormalarından ibarettir. Zorunlu cevaplanmayı gerektiren bu denetim aracı her halükârda kullanılabilecek bir yetkidir. Dolayısıyla cumhurbaşkanı yardımcısı ve bakanların sorulara verdikleri yazılı cevaplar konunun muhatapları tarafindan detaylı bir analize tabi tutulabilecek ve kamuoyunun bilgisine sunulabilecektir.

\subsubsection{Genel Görüşme}

Toplumu ve devlet faaliyetlerini ilgilendiren belli bir konunun, Türkiye Büyük Millet Meclisi Genel Kurulunda görüşülmesidir (m. 98/4). Genel görüşme açılması, siyasî parti grupları veya en az yirmi milletvekili tarafından istenir. Ancak Genel görüşme açllıp açılmamasına Genel Kurul karar verir. Seçim sonuçlarına baktığımızda TBMM'de beş siyasi parti grubu bulunmaktadır. Dolayısıyla herhangi bir siyasi parti grubu, Başkanlığa genel görüşme açılması önergesi verilebilir. Genel Kurul, Genel görüşme açlıp açılmamasına işaretle oylama suretiyle karar verir (TBMM İçtüzük m.102). İşaretle oylamada olumlu oylar, olumsuz 
oylardan fazlaysa, Oy'a konan husus kabul edilmiș; aksi halde, reddedilmiș olur. TBMM Genel Kurulu, Genel görüşme açılmasına karar vermesi halinde, genel görüşme günü özel gündem halinde Danıșma Kurulunca tespit edilir. Genel görüşmenin başlayacağı gün, görüşme açılmasına karar verilmesinden itibaren kırk sekiz saatten önce ve yedi tam günden sonra olamaz. TBMM bu denetim yolu ile idarenin faaliyetlerine ilişkin konuyu, TBMM Genel Kurulunda ele alır ve irdeler, fakat herhangi bir oylamaya gidilmez.

\subsubsection{Meclis Araștırması}

Meclis araştırması, belli bir konuda bilgi edinmek için yaplan incelemeden ibarettir. Meclis araştırmasının açılmasında genel görüşme açılmasındaki hükümler uygulanır (İçtüzük md.104). Meclis araştırmasının yürütülmesi görevi, genel hükümlere göre seçilecek bir özel komisyona verilir. Meclis araştırma komisyonu bakanlıklarla genel ve katma bütçeli dairelerden, mahallî idarelerden, muhtarlıklardan, üniversitelerden, Türkiye Radyo-Televizyon Kurumundan, kamu iktisadî teşebbüslerinden, özel kanun ile veya özel kanunun verdiği yetkiye dayanılarak kurulmuş banka ve kuruluşlardan, kamu kurumu niteliğindeki meslek kuruluşlarından ve kamu yararına çalışan derneklerden bilgi istemek ve buralarda inceleme yapmak, ilgililerini çağırıp bilgi almak yetkisine sahiptir. Bu yolla Meclis, Cumhurbaşkanı yardımcıları ve Bakanların faaliyetlerini, araştırma komisyonları yoluyla denetler. Bu denetim yetkisi de çoğunluğun bu yönde iradesine dayanarak açlabilecektir. Haliyle çoğunluk yani Cumhur ittifakının isteği söz konusu olmaz ise TBMM'nin bu yetkisini kullanması zor görülmektedir.

\subsubsection{Cumhurbaşkanı Yardımcıları ve Bakanların Soruşturulması ve Yüce Divana Sevki}

Cumhurbaşkanı yardımcısı ve Bakanlar hakkında 106. maddenin beşinci, altıncı, yedinci fikraları uyarınca yapılan soruşturmadan ibarettir. Görevde bulunan veya görevden ayrılmış olan Cumhurbaşkanı yardımcısı ve bakanlar hakkında görevleri ile ilgili suç işledikleri iddiasıyla Türkiye Büyük Millet Meclisi soruşturma denetimi yapabilir (İçtüzük md. 107). Buna göre Cumhurbaşkanı yardımcıları ve bakanlar hakkında görevleri ile ilgili suç işledikleri iddiasıyla Türkiye Büyük Millet Meclisi üye tamsayısının salt çoğunluğunun vereceği önergeyle soruşturma açılması istenebilir. Meclis, önergeyi en geç bir ay içinde görüşür ve üye tamsayısının bește üçünün gizli oyuyla soruşturma açılmasına ve üye tam sayısının üçte ikisinin gizli oyuyla Yüce Divana sevk kararı vermesine yol açan denetim yoludur. Başkanlık sitemlerinde bulunmayan bu denetim yolu Cumhurbaşkanlığı hükümet sisteminin bir özelliği olarak düzenlenmiş önemli bir denetim aracıdır. Mevcut dağılıma ve anayasal hükümlere göre Meclis'in bu denetim yetkisini kullanabilmesi olağan koşullarda mümkün gözükmemektedir. Aynı zamanda Yüce Divana sevk edilen ve yargılaması devam eden Cumhurbaşkanı anayasal yetkilerini kullanmaya devam edebilirken, sadece seçim kararı alamaz ve bu yolla TBMM'ni feshetme yetkisini kullanamaz. $\mathrm{Bu}$ durumda CHS'de düzenlenmiş olan ayrı bir tür denetim ve önlemdir

\section{SONUÇ}

Çalışmada devlet yönetimin önemli unsurlarında biri olan "denetim" süreci siyasi denetim olgusu çerçevesinde ve 24 Haziran 2018 tarihide yapılan yeni sistemin ilk seçim sonuçlarına göre TBMM'nin, yürütme organını (Cumhurbaşkanı) denetleme araçları çerçevesinde değerlendirilmiştir. Anayasal sistem olarak Türkiye Büyük Millet Meclisi'nin Cumhurbaşkanı ve idareyi Türk Milleti adına denetlemesi, yasama yetkisinin doğal bir sonucudur. Yeni sistemde Meclisin, yürütmeyi denetimleme araçlarına baktığımızda birincisi yasama yetkisinin yalnızca TBMM'ne bırakılmış olmasıdır. Kanun yapma yetkisi sadece milletvekillerine tanınmış bir yetkidir ve bu durum Meclisin üstünlüğü prensibinin açıkça kabulü anlamına gelir. Yasama yetkisi üzerinden Meclisin denetim yapabileceği diğer bir alan ise Cumhurbaşkanı Kararnamelerine ilişkin yetkidir. Cumhurbaşkanı, Kararname 
yetkisini kullanırken anayasa ve kanunla konu bakımından bir sınırlamaya tabi kılındığı gibi kararnameler ayrıca olağan dönemlerde Anayasa Mahkemesinin denetimine de tabidir. Olağanüstü dönemlerde çıkarılacak olan kanun gücünde Cumhurbaşkanlığı kararnameleri için ise yeni sistem Meclise üç ay içerisinde karara bağlama kararı vermek suretiyle siyasi denetim yetkisini ilk kez tanımıştır.

Türkiye'de hükümet sistemi değişikliği getiren 6771 sayılı Anayasa değişiklik kanunu TBMM'ye, yürütmeyi denetleme araçları bakımından yeni usuller getirmiștir. Öyle k, bu yeni sistemde bașkanlık sistemlerinde var olmayan birçok yöntemin geniş ve ayrıntılı bir şekilde bizzat anayasada belirtilmek suretiyle yer aldığı görülmektedir. Bunlar arasında TBMM'nin Cumhurbaşkanı yardımcısı ve bakanlar tarafindan yazılı cevaplanma gerektiren soru ve genel görüşme açma istemleri yanında; yine ayrıca yürütme görevini yerine getirirken görevleri ile ilgili bir suç işledikleri iddiasıyla cumhurbaşkanı yardımcısı ve bakanlar hakkında "meclis soruşturması açılması ve meclis araştırması" yoluyla faaliyetlerinin denetime tabi tutulması bulunmaktadır.

Yeni siyasal sistemin en önemli unsuru yürütmenin hesap verilebilir bir yönetim anlayıșını hakim kılmasıdır. Cumhurbașkanının yetki sorumluluk dengesi bir bütün olarak değerlendirildiğinde çok geniş yetkilere sahip bir Cumhurbaşkanın sorumsuzluğu ve denetimden yoksunluğu düşünülemez. $\mathrm{Bu}$ yönüyle cumhurbașkanının halka hesap verebilir konumda bulunması yanı sıra, TBMM tarafından çeşitli araçlarla denetleniyor olması hem halk hem de halkın doğrudan seçtiği Meclis tarafindan denetlenmesini sistemin dikkate değer unsurlardır.

CHS, yürütme organını (cumhurbaşkanı) sadece siyasi değil aynı zamanda hukuki, idari ve cezai sorumluluğu anlamında denetimine ilişskin önemli düzenlemeler getirmiştir. $\mathrm{Bu}$ sistemde yasama-yürütme organları ayrı ayrı seçimlerle belirleniyor olsa bile yürütme organının denetiminde Meclisin etkinliği, verimliliği ve bağımsızlığı parlamenter sistemden farklı olarak belirgin hale gelmiştir. Devlet idaresinde organların bir dengedenetleme içinde kendilerine verilen anayasal yetkileri kullanması doğaldır. Parlamenter sistem uygulamalarına bakıldığında, CHS'de siyasi denetim, zaman ve süre yönünden çeşitli sınırlamalara tabi kılınmış bu yönü ile etkinliğinin artırılması amaçlanmıştır.

\section{KAYNAKÇA}

Aydın Ahmet, (2010), Yönetim Bilimi, Seçkin Yayıncllık, Ankara.

Çam Esat (2000). Çağdaş Devlet Sistemleri Der Yayınları: İstanbul

$$
\text { Eroğlu Cem (1978), }
$$

"Cumhurbaşkanı'nın Denetim İşlevi", AÜSBF Dergisi, C. XXXIII, Ankara.

Eroğlu Cem (1996), Çağdaş Devlet Düzenleri, İmaj Yayıncılık, Ankara.

Ertekin Şaban\&Gül Hüseyin (2018), "Hükümet Sistemlerinin Bütçe Kullanımı Açısından Değerlendirilmesi: Cumhurbaşkanlı̆̆ı Hükümet Sistemi", in Yerelden Globale Stratejik
Araştırmalar III, (ed) Silvius Stancu vd, IJOPEC Publication, London UK.

Eryılmaz Bilal (1994), Kamu Yönetimi, DEÜ Üniversite Kitabevi, İzmir.

Giovanni Sartori (1997), Karşılaştırmalı Anayasa Mühendisliği, (Çev. E. Özbudun) Yetkin Yayınları, Ankara.

Gözler Kemal (2017), Anayasa Hukukunun Genel Esasları, Ekin 9. Baskı, Bursa.

Gözler Kemal (2018), Anayasa Hukukuna Giriş, 27. Baskı, Ekin, Bursa.

Gözler Kemal (2018a), İdare Hukukuna Giriș, Ekin, 24. Basım, Bursa. 
Gözübüyük Şeref \&Tan, Turgut (2003) İdare Hukuku C.II, İdari Yargllama Hukuku, Turhan Kitabevi, Ankara.

Gül Hüseyin (2018), 1923'den 2018'e Türkiye'de Hükümet Sistemi, EfeAkademi Yayınları, İstanbul.

Gülener Serdar\&Miş Nebi (2017), "Cumhurbaşkanliğı Sisteminin Anayasal Tasarımı", in Türkiye'de Siyasal Sistemin Dönüşümü ve Cumhurbaşkanlığı Sistemi, SETA Yayınları, İstanbul

Nur Uluşahin (1999), Anayasal bir Tercih Olarak Başkanlık Sistemi, Yetkin yayınları, Ankara.

Örnek Acar (1994), Kamu Yönetimi, Meram Yayınları., İstanbul.

Özbudun Ergun (2011), Türk Anayasa Hukuku, Yetkin Yayınları, Ankara.

Sancaktar Oğuz vd, (2018), İdare Hukuku: Teorik Çalışma Kitabı, Seçkin 7. Baskı, Ankara.

Şahin Kemal (2001), Yasamanın, Yürütme ve Yargı Üzerinde Kılıcı, Bir Anglo-Amerikan Kurumu, İmpeachment, Beta Yayın, İstanbul.

Yazıcı Serap, (2013), Başkanlık ve YarıBaşkanlık Sistemleri: Türkiye İçin Bir Değerlendirme, Bilgi Üniversitesi Yayın, İstanbul.

http://www.ysk.gov.tr/tr/24-haziran2018-secimleri/77536, rișim.12.10.2018.

http://www.ysk.gov.tr/doc/dosyalar/do cs/24Haziran2018/KesinSecimSonuclari/201 8CB-416D.pdf, erişim. 12.10.2018. 